\title{
Kontekstualisasi Pembelajaran dengan Objek Biologi, Efeknya pada Keterampilan Mahasiswa Merencanakan Pembelajaran
}

\section{Suhirman}

Program Studi Pendidikan Biologi, Universitas Islam Negeri Mataram, Jl. Pendidikan No. 35 Mataram 83125, Indonesia

Email Korespondensi: suhirman@uinmataram.ac.id

\begin{tabular}{|c|c|}
\hline Article Info & Abstract \\
\hline $\begin{array}{l}\text { Article History } \\
\text { Received: October } 2019 \\
\text { Revised: November } 2019 \\
\text { Published: December } 2019 \\
\text { Keywords } \\
\text { contextualization; } \\
\text { biological object; } \\
\text { lesson plan }\end{array}$ & $\begin{array}{l}\text { [Title: Contextualization of Learning with Biological Objects, Its Effect on } \\
\text { Student Skills Planning Learning]. This study aims to describe the impact of the } \\
\text { contextualization oflearning with biological objects on learning planning skills. This type } \\
\text { of quantitative descriptive research with quasi-experimental methods, research design } \\
\text { posttest-only control design. Cluster random sampling is carried out in determining the } \\
\text { research sample consisting of } 80 \text { experimental and control classes in the sixth semester of } \\
\text { the Department of Natural Sciences of Biology, FTK UIN Mataram. Student skills } \\
\text { planning data for learning are collected with a performance test instrument then analyzed } \\
\text { by t statistics. The results showed that the average value of the experimental class } 65.70 \\
\text { was lower than the control class } 69.13 \text { (p = 0.143> 0.05, meaning that it did not differ } \\
\text { significantly. Thus the contextualization of learning with biological objects did not have } \\
\text { a significant impact on student skills in planning to learn. The planning of learning } \\
\text { biology can be done by students even though they are not dealing directly with the real } \\
\text { object of biology. }\end{array}$ \\
\hline Informasi Artikel & Abstrak \\
\hline $\begin{array}{l}\text { evima: Oktober } 2019 \\
\text { ublikasi: December } \\
9\end{array}$ & \multirow{2}{*}{$\begin{array}{l}\text { Penelitian ini bertujuan untuk mendeskripsikan dampak kontekstualisasi } \\
\text { pembelajaran dengan objek biologi pada keterampilan merencanakan } \\
\text { pembelajaran. Jenis penelitian deskriptif kuantitatif dengan metode quasi } \\
\text { eksperimen, desain penelitian posttest-only control design. Cluster random } \\
\text { sampling dilakukan dalam menentukan sampel penelitian yang terdiri dari kelas } \\
\text { eksperimen dan kontrol yang berjumlah } 80 \text { orang pada semester VI Jurusan } \\
\text { Pendidikan IPA Biologi FTK UIN Mataram. Data keterampilan mahasiswa } \\
\text { merencanakan pembelajaran dikumpulkan dengan instrument tes kinerja } \\
\text { kemudian dianalisis dengan statistik t. Hasil penelitian menunjukkan bahwa nilai } \\
\text { rata-rata kelas eksperimen } 65,70 \text { lebih rendah dibanding kelas kontrol } 69,13 \text { (p } \\
0,143>0,05 \text {, artinya tidak berbeda secara signifikan. Dengan demikian } \\
\text { kontekstualisasi pembelajaran dengan objek biologi tidak memiliki dampak } \\
\text { signifikan pada keterampilan mahasiswa dalam merencanakan pembelajaran. } \\
\text { Perencanaan pembelajaran biologi dapat dilakukan oleh mahasiswa meskipun } \\
\text { tidak berhadapan langsung dengan objek nyata biologi. }\end{array}$} \\
\hline $\begin{array}{l}\text { kunci } \\
\text { ekstualisasi; }\end{array}$ & \\
\hline How to Cite this Article? & $\begin{array}{l}\text { Suhirman. (2019). Kontekstualisasi Pembelajaran dengan Objek Biologi, Efeknya } \\
\text { pada Keterampilan Mahasiswa Merencanakan Pembelajaran. Jurnal Penelitian } \\
\text { dan Pengkajian Ilmu Pendidikan: e-Saintika, 3(2), 96-104. DOI: } \\
\text { https://doi.org/10.36312/e-saintika.v3i2.153 }\end{array}$ \\
\hline
\end{tabular}

\section{PENDAHULUAN}

Sains mempunyai kedudukan yang penting untuk mendorong dan mempersiapkan mahasiswa dalam menghadapai berbagai fenomena dan dinamika 
yang terjadi di dunia nyata. Sains terdiri atas (1) produk mencakup fakta, konsep, prinsip, teori dan hukum dan (2) proses termasuk cara-cara mendapatkan, mengembangkan dan mengimplementasikan pengetahuan yang meliputi cara kerja, berpikir, memecahkan masalah dan bersikap (Asy'ari et al. 2019). Aktivitas pembelajaran sains mestinya dikondisikan berlangsung dalam suasana mengasyikan dan menyenangkan karena dalam mempelajari materi dihadapkan dengan objek yang kontekstual, materi pembelajaraan umumnya berkaitan dengan fenomena yang dialami dan dijumpai di lingkungan sekitar.

Pembelajaran biologi yang menyangkut gejala alam dan realita kehidupan seringkali dipahami secara tekstual (Aida, Hala, \& Danial, 2016). Objek pembelajaran biologi menyangkut fakta, konsep, prinsip, prosedur, teori, dan hukum alam diperoleh melalui serangkaian proses ilmiah (Ruse, 2012; Abruscato, 2014; Sudarisman, 2015; Ali, 2018). Kegiatan ilmiah dapat membantu mahasiswa memahami materi IPA yang disampaikan dengan mendapatkan pemahaman yang menyeluruh (Rahayu, Mulyani, \& Miswadi, 2012) melalui penekanan pada usaha pengembangan keterampilan dan sikap ilmiah (Widiyatmoko, 2013). Pembelajaran biologi memerlukan kegiatan ilmiah sehingga mahasiswa dapat mengembangkan keterampilan dan sikap ilmiah (Aida, Hala, \& Danial, 2016). Oleh sebab itu, dalam perencanaan pembelajaran biologi sebaiknya lebih menekankan pada aktivitas dalam melakukan kegiatan interaksi dengan objek alam untuk menemukan fakta, konsep, prinsip, prosedur, teori, dan hukum sebagaimana saintis bekerja.

Jurusan Pendidikan IPA Biologi Fakultas Tarbiyah dan Keguruan UIN Mataram memiliki profil lulusan profesional dengan kemampuan akademik terukur yang beriman, bertaqwa dan mampu merumuskan, menerapkan, serta mengembangkan konsep IPA Biologi secara teoritis maupun paktis. Mengembangkan dan menyebarluaskan konsep IPA Biologi yang berbasis nilai-nilai keislaman, peningkatan potensi, kearifan local, maupun nasional (Tim Pengembang, 2017).

Kurikulum sebagai software menjadi sangat penting sebagai upaya mewujudkan profil lulusan yang profesional (Mulyono \& Halim, 2015; Fitriani, Widiyatmoko, \& Khusniati, 2016). Kurikulum jurusan pendidikan IPA biologi secara konten menekankan pada komponen kajian keilmuan ilmu biologi (40\%). Kemampuan merencanakan pembelajaran merupakan keterampilan yang sangat penting untuk dimiliki oleh calon guru (Piwowar, Thiel, \& Ophardt, 2013). Mencermati konten struktur kurikulum yang sudah disusun sudah cukup memadai untuk mendapatkan pengalaman belajar mahasiswa agar memiliki komptensi pedagogik dalam merencanakan dan menyelenggarakan pembelajaran biologi di sekolah dan madrasah. Kurikulum UIN Mataram yang berbasis KKNI mempunyai tujuan untuk mata kuliah perencanaan pembelajaran biologi adalah mengembangkan kemampuan mahasiswa merencanakan pembelajaran biologi di sekolah atau madrasah yang meliputi; menganalisis kurikulum IPA Terpadu di MTs/SMP dan kurikulum biologi di MA/SMA, menyusun program tahunan dan program semester, mengembangkan silabus, rencana pelaksanaan pembelajaran, dan intrumen penilaian hasil belajar (Tim Pengembang, 2017).

Berdasarkan tujuan tersebut capaian yang dituntut pada mata kuliah perencanaan pembelajaran biologi disamping kemampuan kognitif, juga memberikan ruang dalam mengembangkan keterampilan atau kinerja mahasiswa untuk 
merencanakan pembelajaran biologi di sekolah atau madrasah. Kemampuan merencanakan menurut kurikulum yang berbasis KKNI adalah mahasiswa memiliki pengetahuan dan keterampilan menganalisis kurikulum, menyusun program tahunan dan program semester, mengembangkan silabus, RPP dan intrumen penilaian.

Hasil analisis peneliti menunjukkan pembelajaran lebih terfokus pada penguasaan konsep yang berkaitan dengan perencanaan, model-model pengembangan sistem instruksioanl, konsep pengembangan indikator, silabus, dan rencana pelaksanaan pembelajaran. Sistem perkuliahan dilaksanakan melalui pemberian tugas secara berkelompok, kemudian ditelaah dan dianalisis. Mahasiswa berdiskusi secara kelompok kemudian langkah berikutnya memberikan kesempatan untuk melakukan presentasi, dan selanjutnya dilakukan tanya jawab dengan anggota kelompok lain serta diakhiri dengan dosen memberikan penguatan atau menjelaskan hal-hal penting tentang materi yang didiskusikan serta tugas individu sebagai feed back konstruktif untuk memperkuat pemahaman mahasiswa.

Pada tahap implementasi, permasalahan yang sering terjadi adalah mahasiswa belum menunjukan kemampuan yang optimal dalam merancang skenario pembelajaran. Kemampuan dalam merumuskan komponen silabus dan rencana pelakasanaan pembelajaran merupakan unsur penting yang dimiliki oleh setiap mahasiswa (Gayatri et al., 2015).

Hasil telaah awal terhadap dokumen RPP yang dikembangkan oleh mahasiswa ketika melakukan persiapan dan simulasi mengajar mata kuliah microteaching ditemukan beberapa kelemahan sebagai berikut: (1) rumusan indikator dan tujuan pembelajaran tidak relevan dengan kompetensi dasar (2) rumusan tujuan pembelajaran dengan belum sesuai dengan kegiatan pembelajaran, materi pokok, media pembelajaran, dan jenis evaluasi yang dipilih; (3) penentuan metode pembelajaran masih belum sesuai dengan indikator maupun tujuan pembelajaran; (4) rumusan tahapan pembelajaran masih belum rinci (5) penentuan media pembelajaran masih belum sinkron dalam lembar kerja siswa.

Agar pemahaman dan keterampilan mahasiswa dalam mata kuliah perencanaan pembelajaran biologi lebih optimal penting dihadirkan objek nyata ketika proses pembelajaran berlangsung. Pembelajaran biologi sebaiknya menghadirkan objek nyata secara kontekstual (Glynn \& Winter, 2004; Suryawati, Osman, \& Meerah, 2010), misalnya pada materi ekosistem ketika sedang menyusun perencanaan pembelajaran biologi dan menelaah kompetensi inti dan KD, idealnya mahasiswa secara langsung berhadap-hadapan dengan ekosistem nyata.

Hasil penelitian sebelumnya menunjukan bahwa pembelajaran yang dilaksanakan dengan suasana kontekstualisasi objek nyata sangat membantu pemahaman dan keterampilan mahasiswa dalam menyusun dan menelaah kompetensi inti dan KD. Hadjerrouit (1999) menekankan perlunya objek dalam pembelajaran untuk membantu siswa membangun dan meningkatkan pengetahuannya. Menurut Cooper, Dann, \& Pausch (2003) menghadirkan objek ketika kegiatan pembelajaran berlangsung merupakan cara terbaik membantu siswa menguasai kompleksitas pemrograman. Ditegaskan Fitriani et al., (2016) model pembelajaran kontekstual berdasarkan topik bahan kimia dalam kehidupan seharihari efektif untuk meningkatkan hasil belajar dan keaktifan siswa. 
Hasil penelitian di atas menunjukkan bahwa menghadirkan objek asli dalam pembelajaran sangat membantu mahasiswa mendesain sebuah program dan memudahkan siswa memahami bahan-bahan kimia yang digunakan dalam kehidupan sehari-hari. Berbeda dengan yang dilakukan dalam penelitian ini, yakni menghadirkan objek biologi dalam menyelenggarakan kegiatan pembelajaran. Keberadaan objek biologi diharapkan membantu mahasiswa dalam menyusun perencanaan pembelajaran.

\section{METODE}

Penelitian ini merupakan penelitian deskriptif-kuantitatif dengan quasi eksperimen. Posttest-only control design dilakukan dalam penelitian ini dengan cluster random sampling digunakan untuk menentukan sampel sebanyak 80 mahasiswa. Pada kelas eksperimen diberlakukan perlakuan kontekstualisasi pembelajaran melalui objek biologi dan kelas kontrol diterapkan pembelajaran reguler, yaitu pembelajaran langsung dan diskusi. Kedua kelas diberikan materi perencanaan pembelajaran biologi sebanyak tujuh kali pertemuan. Selama pembelajaran berlangsung dilakukan pengamatan tentang keterlaksanaan pembelajaran. Setelah selesai rangkaian pembelajaran kemudian diselenggarakan kegiatan pengumpulan data dengan menggunakan instrumen yakni tes. Data yang dikumpulkan berkaitan dengan keterampilan mahasiswa dalam merencanakan pembelajaran.

Ujicoba untuk mengukur validitas dan reliabilitas isntrumen dilakukan dalam penelitian ini yang menunjukkan skor validitas dan reliabilitas 0,76-0,95 dan 0,94. Terdapat tujuh aspek yang diukur dalam keterampilan merencanakan pembelajaran, yaitu keterampilan menganalisis standar isi, keterampilan mengembangkan tujuan pembelajaran, keterampilan mengembangkan materi pembelajaran, keterampilan mengembangan strategi pembelajaran, keterampilan mengembangkan instrumen evaluasi, keterampilan mengembangkan silabus, dan keterampilan mengembangkan rencana pelaksanaan pembelajaran

Penelitian ini juga mengumpulkan data tentang keterlaksanaan pembelajaran dengan menggunakan lembar observasi keterlaksanaan. Hal ini dilakukan dengan tujuan guna memastikan bahwa setiap tahapan pembelajaran yang telah direncanakan dapat dimplementasikan sesuai dengan rencana pembelajarannya.

Data nilai tes keterampilan merencanakan pembelajaran dianalisis dengan teknik statistik deskriptif dan inferensial. Statistik deskriptif memaparkan perbandingan parameter statistik deskriptif pada kelas eksperimen dan kelas kontrol, seperti nilai tertinggi, nilai terendah, rata-rata, dan simpangan baku. Hasil perbandingan secara deskriptif ini digunakan untuk menarik kesimpulan sementara mengenai perbandingan keterampilan mahasiswa pada kelas eksperimen dan kontrol. Statistik inferensial digunakan untuk meyakinkan bahwa perbedaan parameter statistik antara kelas eksperimen dan kontrol terjadi secara signifikan yang menunjukan adanya pengaruh yang signifikan kontekstualisasi pembelajaran dengan objek biologi terhadap keterampilan mahasiswa dalam merencanakan pembelajaran. Statistik yang digunakan adalah statistik-t pada signifikansi 0,05. Seluruh proses analisis statistik dilakukan dengan SPSS versi 16.0.

Data keterlaksanaan pembelajaran berbentuk frekuensi cecklist terhadap opsi ya dan tidak pada item pengamatan. Keterlaksanaan pembelajaran dinyatakan dalam 
persentase yang menggambarkan tingkat keutuhan pelaksanaan rangkaian pembelajaran. Persentase keterlaksanaan pembelajaran menggunakan rumus.

$$
\% \text { Keterlaksaan }=\frac{\text { Jumlah langkah PBM terlaksana }}{\text { Jumlah langkah yang harus dilaksanakan }} \times 100 \%
$$

Hasil analisis data keterlaksanaan pembelajaran digunakan sebagai data pendukung untuk menjelaskan hasil keterampilan merencanakan pembelajaran yang dicapai mahasiswa.

\section{HASIL DAN PEMBAHASAN}

Hasil observasi keterlaksanaan pembelajaran dinyatakan dalam persentase, yaitu porsi langkah pembelajaran yang dapat dilakukan oleh dosen dari sejumlah langkah pembelajaran yang direncanakan dalam RPP. Data persentase keterlaksanaan pembelajaran untuk tujuh kali pertemuan pembelajaran disajikan Tabel 1.

Tabel 1. Persentase Keterlaksanaan Pembelajaran

\begin{tabular}{lcc}
\hline Pertemuan/Materi & \multicolumn{2}{c}{ Keterlaksanaan (\%) } \\
& Kelas Eksperimen & Kelas Kontrol \\
\hline I/ Analisis KD & 72 & 91 \\
II/Pengembangan indikator/tujuan & 68 & 100 \\
pembelajaran & & \\
III/Pengembangan materi pembelajaran & 78 & 100 \\
IV/Pengembangan strategi pembelajaran & 96 & 100 \\
V/Pengembangan silabus & 96 & 100 \\
VI/Pengembangan RPP & 96 & 96 \\
VII/Pengembangan instrumen penilaian & 100 & 100 \\
\hline Rata-rata (\%) & 84 & 98 \\
\hline
\end{tabular}

Berdasarkan Tabel 1, rata-rata keterlaksanaan pembelajaran oleh dosen mitra pada kelas eksperimen lebih rendah dibanding pada kelas kontrol. Hal ini menandakan bahwa proses pembelajaran pada kelas kontrol lebih sesuai dengan langkah pembelajaran yang direncanakan.

Setelah selesai pembelajaran dilakukan tes untuk mengukur keterampilan merencanakan pembelajaran biologi mahasiswa pada mata kuliah Perencanaan Pembelajaran Biologi. Data hasil analisis deskriptif nilai tes keterampilan mahasiswa disajikan Tabel 2 berikut.

Tabel 2. Data Perbandingan Nilai Tes Keterampilan Merencanakan Pembelajaran

\begin{tabular}{lcc}
\hline & Kelas Eskperimen & Kelas Kontrol \\
\hline Jumlah mahasiswa unit analisis & 30 & 30 \\
Nilai tertinggi & 83 & 92 \\
Nilai Rendah & 45 & 32 \\
Nilai rata-rata & 65,70 & 69,13 \\
\hline
\end{tabular}


Tabel 2 tersebut menunjukkan secara deskriptif perbandingan hasil belajar keterampilan mahasiswa pada dua kelompok. Nilai rata-rata pada kelas eksperimen, yaitu mahasiswa yang memperoleh pembelajaran dengan pembelajaran kontekstual lebih rendah dibanding pada kelas kontrol yang mengikuti pembelajaran dengan pembelajaran reguler. Di samping itu, nilai keterampilan tertinggi juga dicapai pada kelas kontrol dibanding eksperimen.

Uji statistik dengan t-tes terhadap data keterampilan merencanakan pembelajaran yang dilakukan untuk mengetahui signifikansi perbedaan nilai ratarata mahasiswa antara kelas eksperimen dengan kontrol. Hasil uji statistik disajikan pada Tabel 3.

Tabel 3. Keterampilan Merencanakan Pembelajaran

\begin{tabular}{llcccrr}
\hline & & \multicolumn{5}{c}{ t-test for Equality of Means } \\
\cline { 2 - 7 } & \multicolumn{4}{c}{$\begin{array}{c}\text { Sig. (2- } \\
\text { Nailed) }\end{array}$} & $\begin{array}{c}\text { Mean } \\
\text { Difference }\end{array}$ & $\begin{array}{c}\text { Std. Error } \\
\text { Difference }\end{array}$ \\
\hline Nilai & $\begin{array}{l}\text { Equal variances } \\
\text { assumed }\end{array}$ & -1.015 & 58 & .314 & -3.433 & 3.382 \\
& $\begin{array}{l}\text { Equal variances not } \\
\text { assumed }\end{array}$ & -1.015 & 49.829 & .315 & -3.433 & 3.382 \\
\hline
\end{tabular}

Tabel 3 menunjukan bahwa nilai sig. = 0,314 lebih besar dari signifikansi yang ditetapkan, yaitu 0.05, artinya $\mathrm{H} 0$ yang menyatakan tidak ada perbedaan rata-rata nilai keterampilan mahasiswa dalam merencanakan pembelajaran antara kelas eksperimen dan kelas kontrol diterima. Kontekstualisasi objek biologi dalam pembelajaran tidak memberikan efek yang signifikan terhadap keterampilan mahasiswa dalam merencanakan pembelajaran. Hal ini sejalan dengan hasil penelitian Risnani bahwa kemampuan calon guru (preservice teacher) biologi dalam merencanakan pembelajaran berbasis keterampilan proses sains (science process skills) masih rendah (Risnani, 2017). Kemampuan mahasiswa dalam merancang pembelajaran konservasi biodiversitas masih lemah (Leksono, Rustaman, \& Redjeki, 2013).

Berbeda dengan hasil penelitian sebelumnya, yaitu Hadjerrouit (1999) yang menyatakan bahwa objek dalam pembelajaran membantu siswa untuk membangun pengetahuan. Demikian halnya Cooper, Dann, \& Pausch (2003) yang menyimpulkan dari penelitiannya, bahwa menghadirkan objek pada pembelajaran adalah cara terbaik untuk membantu siswa menguasai kompleksitas pemrograman. Penerapan critical review terhadap buku guru IPA kurikulum 2013 dapat mengembangkan kemampuan mahasiswa dalam menyusun perangkat pembelajaran berpendekatan saintifik (Khusniati \& Pamelasari, 2014). Perangkat pembelajaran IPA Terpadu model Susan Loucks-Horsley yang dikembangkan efektif untuk meningkatkan sikap IPA, keterampilan proses IPA dan penguasaan materi IPA (Junaidi, Paidi, \& Atiarani, 2014). Implementasi perangkat pembelajaran berbasis masalah dapat meningkatkan kemampuan penguasaan konsep biologi (Paidi, 2011). Pengembangan perangkat pembelajaran IPA Biologi bervisi SETS dapat menumbuhkembangkan kreatifitas dan kemampuan berkomunikasi ilmiah siswa (Rasyid, 2017). 
Hal ini disebabkan karena pada proses kontekstualisasi mahasiswa dihadapkan pada objek nyata biologi sekaligus dokumen standari isi kurikulum pada saat bersamaan melakukan kegiatan perencanaan pembelajaran. Mahasiswa diharapkan menelaah dan menganalisis dua komponen sekaligus pada saat yang bersamaan, yakni menelaah objek biologi dan menganalisis standar isi. Berdasarkan wawancara tidak terstruktur dengan mahasiswa diperoleh informasi bahwa mahasiswa seringkali mengalami kebingungan dalam mengerjakan tugas-tugas perencanaan karena harus menelaah dokumen standar isi sekaligus mencermati media biologi yang diberikan. Mahasiswa nampaknya terlalu lama menganalisis kedua objek tersebut, pemusatan perhatian yang lebih lama, sehingga ketika mengerjakan tugasnya mahasiswa terlihat terburu-buru sebab terbatasnya alokasi waktu disiapkan. Hal ini berdampak pada kurang tuntasnya penyelesaian tugas yang dilakukan mahasiswa, mahasiswa memberikan perhatian yang terlalu lama dan lebih aktif dengan objek biologi. Hal ini nampaknya mahasiswa belum adaptif dalam menjalankan skenario pembelajaran. Menurut Teimourtash \& Yazdani Moghaddam (2017), ketika mahasiswa berhadapan dengan objek atau masalah, siswa cenderung membutuhkan waktu untuk melaksanakan kegiatan berpikir.

Berbeda halnya dengan kelompok yang mengalami pembelajaran hanya dengan menelaah dan menganalisis dokumen standar isi yang tertuang dalam Peraturan Menteri Pendidikan. Saat pembelajaran mahasiswa lebih fokus menelaah dan menganalisis dokumen tanpa harus diburu oleh waktu walaupun tidak berhadapan dengan objek nyata pembelajaran yang direncanakan. Ketika mahasiswa melakukan aktivitas; mengembangkan indikator, menyusun silabus, mengembangkan tahapan proses pembelajaran, dan menyusun instrumen penilaian untuk materi atau topik tentang ekosistem, mahasiswa cukup menelaah dan menganalisis kompetensi dasar secara berulang-ulang.

\section{KESIMPULAN}

Berdasarkan hasil penelitian dapat disimpulkan bahwa kontekstualisasi pembelajaran dengan objek biologi tidak berpengaruh signifikan terhadap keterampilan mahasiswa dalam merencanakan pembelajaran.

\section{SARAN}

Supaya keterampilan mahasiswa merencanakan pembelajaran lebih optimal melalui kontekstualisasi dengan objek biologi, kaidah-kaidah dan langkah pembelajaran sesuai dengan skenario pembelajaran kontekstual benar-benar diimplementasikan berdasarkan sintaknya. Dalam mengkontekstualisasikan pembelajaran dengan objek biologi, dosen sebaiknya menerangkan dengan sejelasjelasnya langkah-langkah pembelajaran yang dilakukan dan menyampaikan informasi tentang pentingnya menghadirkan objek biologi dalam perencanaan pembelajaran. Penataan kembali aspek perencanaan perkuliahan kontekstualisasi objek biologi menjadi sangat penting agar keterampilan mahasiswa merencanakan pembelajaran menjadi lebih meningkat.

\section{UCAPAN TERIMA KASIH}

Penelitian ini tidak menerima hibah khusus dari agensi pendanaan mana pun di sektor publik, komersial, atau nirlaba. 


\section{DAFTAR PUSTAKA}

Abruscato. (2014). Teaching Children Science: a Discovery Approach. New York: Allyn and Bacon.

Aida, N., Hala, Y., \& Danial, M. (2016). Pengembangan Perangkat Pembelajaran Biologi Berbasis Inkuiri pada Materi Sistem Ekskresi. Jurnal Bionature, 17(1), 115124.

Ali, L. U. (2018). Pengelolaan Pembelajaran IPA Ditinjau dari Hakikat Sains pada SMP di Kabupaten Lombok Timur. Prisma Sains: Jurnal Pengkajian Ilmu Dan Pembelajaran Matematika Dan IPA IKIP Mataram, 6(2), 103. https:/ / doi.org/10.33394/j-ps.v6i2.1020

Asy'ari, M., Fitriani, H., Zubaidah, S., \& Mahanal, S. (2019). The Science Process Skills of Prospective Biology Teachers in Plant Cell Material Based on Gender. International Journal of Emerging Technologies in Learning (iJET), 14(19), 168-178.

Cooper, S., Dann, W., \& Pausch, R. (2003). Teaching Objects-first in Introductory Computer Science. SIGCSE Bulletin (Association for Computing Machinery, Special Interest Group on Computer Science Education), 191-195. https:/ / doi.org/10.1145/792548.611966

Dirjen DIKTI. (2011). Pengembangan Profesi Guru. Jakarta: Pendidikan Tinggi, Departemen Pendidikan Nasional.

Fitriani, N. R., Widiyatmoko, A., \& Khusniati, M. (2016). The Effectiveness of CTL Model Guided Inquiri-based in the Topic of Chemicals in Daily Life to Improve Students' Learning Outcomes and Activeness. Jurnal Pendidikan IPA Indonesia, 5(2), 278-283. https:// doi.org/10.15294/jpii.v5i2.6699

Gayatri, Y., Fiqriyati, A., Rahmayati, K., \& Listiana, L. (2015). Peningkatan Penguasaan Konsep, Kemampuan Merancang Skenario Pembelajaran Biologi dan Komunikasi Mahasiswa Melalui Pemodelan pada Perkuliahan Strategi Belajar Mengajar. Didaktis, 15(2), 68-81.

Glynn, S. M., \& Winter, L. K. (2004). Contextual Teaching and Learning of Science in \% Elementary Schools. Journal of ELementery Science Education, 16(2), 3-4.

Hadjerrouit, S. (1999). A Constructivist Approach to Object-oriented Design and Programming. SIGCSE Bulletin (Association for Computing Machinery, Special Interest Group on Computer Science Education), 31(3), 171-174. https:/ / doi.org/10.1145/384267.305910

Junaidi, Paidi, Atiarani, V., \& SR, R. D. S. (2014). Pengembangan Perangkat Pembelajaran IPA Terpadu Model Susan Loucks-Horsley. Jurnal Kependidikan, 44(1), 15-25.

Khusniati, M., \& Pamelasari, S. D. (2014). Penerapan Critical Review Terhadap Buku Guru IPA Kurikulum 2013 untuk Mengembangkan Kemampuan Mahasiswa dalam Menyusun Perangkat Pembelajaran Berpendekatan Saintifik. Jurnal Pendidikan IPA Indonesia, 3(2), 168-176.

Leksono, S. M., Rustaman, N., \& Redjeki, S. (2013). Kemampuan Profesional Guru Biologi Dalam Memahami dan Merancang Model Pembelajaran Konservasi Biodiversitas Di SMA. Cakrawala Pendidikan, XXXII(3), 408-419.

Mulyono, H., \& Halim, N. (2015). Literasi Informasi dan Kritis: Urgensi, Perspektif Islam, dan Integrasi dalam Kurikulum Pendidikan. Jurnal Tarbiyah, 22(2), 46-54.

Paidi. (2011). Pengembangan Perangkat Pembelajaran Biologi Berbasis Masalah. 
Jurnal Kependidikan, 41(2), 185-201.

Pengembang, T. (2017). Kurikulum UIN Mataram Berbasis KKNI. Mataram: Universitas Islam Negeri Mataram.

Piwowar, V., Thiel, F., \& Ophardt, D. (2013). Training Inservice Teachers' Competencies in Classroom Management. a Quasi-experimental Study with Teachers of Secondary Schools. Teaching and Teacher Education, 30(1), 1-12. https://doi.org/10.1016/j.tate.2012.09.007

Rahayu, P., Mulyani, S., \& Miswadi, S. S. (2012). Pengembangan Pembelajaran IPA

Terpadu dengan Menggunakan Model Pembelajaran Problem Base Melalui Lesson Study. Jurnal Pendidikan IPA Indonesia, 1(1), 63-70.

Rasyid, A. (2017). Pengembangan Perangkat Pembelajaran Biologi Bervisi SETS Kompetensi Ekologi dan Kerusakan Lingkungan Sekolah Menengah Atas. Jurnal Bio Educatio, 2(April), 9-17.

Risnani, L. Y. (2017). Kemampuan Calon Guru (Pre-service Teacher) Biologi Merencanakan Pembelajaran Berbasis Keterampilan Proses Sains (Science Process Skills). Bioedukasi, Jurnal Pendidikan Biologi, 8(2), 102-116.

Ruse, M. (2012). What the Philosophy of Biology is: Essays Dedicated to David Hull. Springer Science \& Business Media.

Sudarisman, S. (2015). Memahami Hakikat dan Karakteristik Pembelajaran Biologi Dalam Upaya Menjawab Tantangan Abad 21 serta Optimalisasi Implementasi Kurikulum 2013. Florea: Jurnal Biologi dan Pembelajarannya, 2(1), 29-35. https:/ / doi.org/10.25273/ florea.v2i1.403

Suryawati, E., Osman, K., \& Meerah, T. S. M. (2010). The Effectiveness of Contextual Teaching and Learning on Student's Problem Solving Skills and Scientific Attitude. Procedia-Social and Behavioral Sciences, 9, 1717-1721. https://doi.org/10.1016/j.sbspro.2010.12.389

Teimourtash, M., \& Yazdani Moghaddam, M. (2017). On the Plausibility of Bloom's Higher Order Thinking Strategies on Learner Autonomy: The Paradigm Shift. Asian-Pacific Journal of Second and Foreign Language Education, 2(1). https:/ / doi.org/10.1186/s40862-017-0037-8

Widiyatmoko, A. (2013). Pengembangan Perangkat Pembelajaran IPA Terpadu Berkarakter Menggunakan Pendekatan Humanistik Berbantu Alat Peraga Murah. Jurnal Pendidikan IPA Indonesia, 2(1), 76-82. 